\title{
Kultura oratorska w kręgu Radziwiłłów birżańskich. Nieznane mowy Piotra Kochlewskiego i Salomona Rysińskiego
}

Dotychczasowe badania nad kulturalnym środowiskiem panów na Birżach i Dubinkach, skupiające się raczej na piśmiennictwie ${ }^{1}$ powstałym w tym kręgu, w małym stopniu uwzględniały sztukę żywego słowa. Dwór Radziwiłłów może być jednak także przykładem aktywności oratorskiej patronów i ich sług zaznaczających swoją obecność w życiu publicznym poprzez zabieranie głosu na różnych uroczystościach rodzinnych i państwowych.

O „chwalebnej swadzie” Krzysztofa Radziwiłła wielokrotnie wypowiadano się z uznaniem w XVII w., hetman często był proszony o to, aby w imieniu rodziny wyrazić podziękowania za uczestnictwo w pogrzebie i zaprosić na „tzami oblany chleb”2. Kopiowano jego mowy

1 Zob. A. Sajkowski, Od „Sierotki” do „Rybeńki”. W kręgu radziwittowskiego mecenatu, Wydawnictwo Poznańskie, Poznań 1965; J. Dürr-Durski, Daniel Naborowski. Monografia z dziejów manieryzmu i baroku w Polsce, Ossolineum, Łódź 1966, s. 94-98; J. Pelc, W. Tomkiewicz, Rola mecenatu $w$ rozwoju kultury i literatury polskiej $w$ czasach renesansu oraz baroku, w: Problemy literatury staropolskiej. Seria druga, red. J. Pelc, Ossolineum, Wrocław 1973, s. 213-216; M. Jarczykowa, Książka i literatura w kręu Radziwittów birżańskich w pierwszej potowie XVII wieku, Wydawnictwo Uniwersytetu Śląskiego, Katowice 1995; U. Augustyniak, Dwór i klientela Krzysztofa Radziwitta (1585-1640). Mechanizmy patronatu, Wydawnictwo Naukowe Semper, Warszawa 2001; K. Gajdka, Literatura, propaganda, stużba. Ludzie pióra w otoczeniu Radziwittów birżańskich w pierwszej potowie XVII wieku, Wydawnictwo Naukowe Semper, Warszawa 2009.

2 Zob. M. Jarczykowa, „Chwalebna swada” Radziwitta. Mowy pogrzebowe Krzysztofa II, w: Studia bibliologiczne, t. 7, red. B. Zyska, A. Jarosz, UŚ, Katowice 1993, s. $15-28$. 
parlamentarne, „rzeczy” na weselach, przemówienie przy przyznawaniu „sprawnych lat” synowi ${ }^{3}$. Starszego brata hetmana, Janusza, również ceniono jako mówcę, szczególnie zaś chętnie przepisywano jego wystąpienie przy konkluzji sejmu $1613 \mathrm{r}^{4}$

Na dworze w Birżach często przygotowywano oracje dla swoich panów, w korespondencji pojawiają się wzmianki o „formowaniu” mów prezentowanych potem na „placu sarmackiej swady”. Oprócz „rzeczy” zapisywanych pod nazwiskami Radziwiłłów, dworzanie birżańscy zabierali też głos we własnym imieniu, co zostało zaznaczone w tytułach powielonych tekstów przemówień. Aktywnymi oratorami byli Samuel Przypkowski, który kompetentnie występował na forum publicznym i w czasie uroczystości rodzinnych, oraz Piotr Kochlewski, wygłaszający mowy na sejmach, ślubach, pogrzebach i innych uroczystych ceremoniach. Sędzia ziemi brzeskiej jako oficjalny przedstawiciel Krzysztofa Radziwiłła wręczał upominki na ślubie Cecylii Renaty z Władysławem IV i wygłaszał łacińską mowę do królowej. Przedstawiał też polskie oracje - publicznie gratulował patronowi nominacji na urząd wojewody wileńskiego, wyrażając radość w imieniu wszystkich sług hetmana, zabierał głos na pogrzebach Marcjana Tryzny i Kossakowskiego ${ }^{6}$.

Oprócz tych „rzeczy” w siedemnastowiecznych sylwach kopiowano także inne mowy Piotra Kochlewskiego. Są to: wystąpienia na weselu Władysława Dorohostajskiego, oracja na zaślubinach Pawła Demitrowicza, oratio funebris poświęcona matce, Dorocie z Madalińskich, i - prawdopodobnie - „rzecz” na pogrzebie Stankiewicza.

W odniesieniu do mów weselnych autorstwo Kochlewskiego zostało wyraźnie zaznaczone w tytule, gdzie podano miejsce, daty i okoliczności wystąpień. Oracja „na weselu ks[ię]dza Pawła Demitrowicza w Kiejdanach, gdy pannę Biryłowiczównę pojmował Anno 1632” zachowała się

3 Zob. M. Jarczykowa, Oratorska oprawa "przyznawania lat” Januszowi Radziwittowi (1612-1655), w: Proza staropolska, red. K. Płachcińska, M. Bauer, UŁ, Łódź 2011, s. $73-83$.

4 Zob. M. Barłowska, Swada i milczenie. Zbiory oratorskie XVII-XVIII wieku - prolegomena filologiczne, UŚ, Katowice 2010, s. 302.

5 Zob. M. Jarczykowa, „Papirowe materie” Piotra Kochlewskiego. O dziatalności pisarskiej sekretarza Radziwittów birżańskich w pierwszej potowie XVII wieku, UŚ, Katowice 2006, s. 141-142.

6 Szerzej o tych mowach por. ibidem, s. 142-165. 
w rękopisie Archiwum Głównego Akt Dawnych7. Kochlewski zabrał głos na weselu ministra kalwińskiego, którego znał osobiście i wysoko cenił. Ich związki zacieśniły się w czasie wspólnego pobytu w Kiejdanach, kiedy to Demitrowicz był głównym opiekunem i nauczycielem księcia Bogusława pobierającego nauki w tutejszej szkole ${ }^{8}$. Nadzór nad edukacją Radziwiłła pełnił Daniel Naborowski, ale w czasie jego nieobecności obowiązki opiekunów przejmowali Demitrowicz ${ }^{9}$ i Kochlewski, który zapewniał księcia Krzysztofa o trosce o jego bratanka. Listy starosty kiejdańskiego skierowane do patrona są świadectwem uznania dla ministra:

Ks[iądz] Demetrius i ks[ięcia] Bogusława pilen, i katedry, na której wielce mu P. Bóg błogosławi i zbór tuteczny różnowiercami obsadzony [...]. Ma wielkie dary Boże. ${ }^{10}$

W pertraktowaniu warunków uposażenia dla nauczyciela Kochlewski odwoływał się do jego wykształcenia: „Ks[iądz] Demetrius musi koniecznie być karmiony. Wszak W.Ks.M. wiesz j[eg]o facultates" ${ }^{\prime 1}$. Być może była to zrozumiała dla księcia aluzja do studiów Demitrowicza w Altdorfie, gdzie cieszył się opinią dobrego mówcy ${ }^{12}$. Oprócz tego ksiądz publikował różne utwory: kompendium historyczne dotyczące dziejów Polski i druki okolicznościowe wydawane w Wilnie, m.in. poświęcone najbliższym zmarłym Krzysztofa Radziwiłła — jego synowi

7 Archiwum Główne Akt Dawnych (dalej AGAD), Zbiór Branickich z Suchej S-38-M, s. 156. W sylwie jest wiele materiałów związanych z Kochlewskim, m.in. jego listy do podstolego litewskiego Piotra Wojny (1631), do podczaszego litewskiego Mikołaja Wiesiołłowskiego (1632), do kasztelana łęczyckiego.

8 AGAD (Archiwum Radziwiłłów, dalej AR), dz. V, 6956, list z 28 III 1629. Z listu Kochlewskiego wiemy, jakie były obowiązki i uposażenie księdza: „Ks. Demetrowicz żył dotąd z leguminów dwornych, potym przychylając się do deklaracji W.Ks.M. żeś go eodem stipendio jako w Słucku mieć chciał, postanowiliśmy obaj z nim, iż do synodu ma wziąć ode mnie jako za jedną ćwierć złot[ych] 125. A nadto o żadnej rzeczy nie mam wiedzieć. On jednak sam do stołu książęcego chodzić i koło jego instytucji pracować ma. Wszak W.Ks.M. pomnisz, że on miał na rok złot[ych] 500”.

9 Kochlewski donosił księciu Krzysztofowi, że Demetrowicz „gotów do księcia Bogusława [...] instytucją privatas bądź publicas na każdy dzień lectionem discentibus podawać", wskazując zarazem na wymagania finansowe kaznodziei. Ibidem, list z Kiejdan z 2 VI 1629.

10 Ibidem, list z Kiejdan z 11 IV 1629.

11 Ibidem, cz. 1, s. 115.

12 Zob. H. Kunstmann, Salomon Rysinsski i norymberski uniwersytet $w$ Altdorfie, OiRwP, 1975, 20, s. 151. 
Jerzemu i bratu Januszowi ${ }^{13}$. W aktach synodów z 1634 r. odnotowano też pracę Demitrowicza „contra Moscorovium”, czyli polemikę z Hieronimem Moskorzewskim ${ }^{14}$. Kochlewski, eksponując w mowie weselnej dokonania pana młodego w służbie kościelnej i publicznej, powoływał się na Radziwiłła - ucznia Demitrowicza: „ta kwitnąca Domu Radziwiłłowskie[g]o latorostka, Ks[ia]żę Je[g]o M[o]ść, pan Bogusław, jako haniebny świadek i asystent tych je[g]o zasług na tym placu stoi" ${ }^{15}$.

Mówca, mając świadomość, że na kreację ministra może wpływać wzór osobowy duchownego, wyraźnie zadeklarował, że chce przedstawić rzeczywiste zalety Demitrowicza i odwoływał się do słuchaczy jako świadków wysokich przymiotów „pobożnego męża”:

Bo iż z udzielnymi osoby własnościami powaga pasterskiej profesyjej jest złączona, przetoż obawiam się, abym, chwaląc własne je[g]o przyrodzone cnoty, nie zdał się dyrygować przymiotom pasterskim. [...] tak i ja trzema słowy moje prawdziwe (bo jakom daleki od pochlebstwa, wiadomo to wielom WMM) prawdziwe mówię rozumienie o tym pobożnym mężu powiem. Iż go dobroć przyrodzona, godność wysoka, miłość ludzka, tak w tym człeku konkurują, że trudno znaleźć, kto by mu w tym zrównał [...]. Jeśli się w tym mylę, apeluję do wszystkich WMM serc i rozsądków. ${ }^{16}$

Kochlewski poprzez pytania retoryczne wskazywał takie cechy księdza Pawła, jak: życzliwość, mądrość, „przyjemne obyczaje”. Oprócz pochwały pana młodego wypowiadał się też w superlatywach o przymiotach jego żony. Zauważył jednak, że małżeństwo ministra jest szczególnie obserwowane i musi świecić przykładem:

[...] domy sług i posłańców Bożych na wysokiej górze stojących i na oczy, i szacunki ludzkie wytknionych nie mają żadnej naganie podlegać, ale owszem jako kryształ przé́roczysty wszytkich cnót i obyczajów przystojnych blask z siebie mają dawać. ${ }^{17}$

13 Zob. S. Kot, Demitrowicz Pawet, w: PSB, t. V/2, z. 22, PAU, Kraków 1939, s. 104.

14 Zob. Akta synodów prowincjonalnych Jednoty Litewskiej 1626-1637, oprac. M. Liedke, P. Guzowski, Wydawnictwo Naukowe Semper, Warszawa 2011, s. 128.

15 Mowa Jelg]o Mci Pana Kochlewskiego na weselu ks[ię]dza Pawta Demitrowicza w Kiejdanach, gdy panne Birytowiczówne pojmowat A[nn]o 1632, AGAD, Zbiór Branickich z Suchej S-38-M, s. 157.

16 Ibidem.

$17 \quad$ Ibidem, s. 158. 
Demitrowicz zawierał powtórny związek małżeński, co dla Kochlewskiego było szczególnie dobrym pretekstem, by podnosić zalety matrimonium, zgodnie z zaleceniami teoretyków wymowy ${ }^{18}$ oraz z wartościowaniem tego stanu przez przywódców reformacji ${ }^{19}$ :

Jeśli w której materyjej rozum i język ludzki może się popisać, tedy w zaleceniu stanu małżeńskie[g]o, bo choćby też kto tępy był, przecie sama zacność, same pożytki, same przywileje stanowi temu Boskiemi i ziemskiemi statutami nadane, uczynią go wymowny[m]. ${ }^{20}$

Następną okazją do wychwalania nowożeńców było wesele Władysława Dorohostajskiego, który 12 lutego 1634 r. pojmował za żonę Elżbietę Podbereską, marszałkównę bracławską. Datę ślubu znajdziemy $\mathrm{w}$ tytule jednej z oracji sędziego ziemskiego brzeskiego, natomiast Jan Seredyka przesuwał wesele Dorohostajskiego na koniec 1630 lub najpóźniej na 15 lipca 1631 r. na podstawie deklaracji Władysława ${ }^{21}$, który liczył wtedy 16 lat. Bardziej prawdopodobną datą jest jednak rok podany w przekazie mowy Kochlewskiego, zwłaszcza że syn marszałka wielkiego litewskiego w 1632 r. wyjechał na studia, a w 1633 towarzyszył księciu Januszowi Radziwiłłowi w jego misji poselskiej do Londynu $^{22}$. Poza tym, w testamencie Władysława z 1632 r. Elżbieta Samsonówna Podbereska jest wspomniana jako „miłościwa panna”, której Dorohostajski darował „na nieprzepominanie na pierścień piętnaście tysięcy"23.

18 Zalecenia pochwały małżeństwa w oracjach weselnych pojawiały się już w opracowaniach retorów starożytnych — Menandra z Leodycei i Pseudo-Dionizjusza. Zob. M. Trębska, Staropolskie szlacheckie oracje weselne. Genologia, obrzęd, źródta, IBL, Warszawa 2008, s. 22-27.

19 Zob. M. Bogucka, Kobieta w spoteczeństwie polskim XVI-XVIII wieku na tle porównawczym, Trio, Warszawa 1998, s. 93.

20 Mowa Je[g]o Mci Pana Kochlewskiego na weselu ks[ię]dza Pawta Demitrowicza..., s. 156.

21 Por. J. Seredyka, Księżniczka i chudopachotek. Zofia z Radziwittów Dorohostajska i Stanistaw Tyminski, Uniwersytet Opolski, Opole 1995, s. 124.

22 Por. M. Chachaj, Zagraniczna edukacja Radziwittów od początku XVI do potowy XVII wieku, UMCS, Lublin 1995, s. 83.

23 Testament Wtadystawa Monwida Dorohostajskiego, w: U. Augustyniak, Testamenty ewangelików reformowanych $w$ Wielkim Księstwie Litewskim, Wydawnictwo Naukowe Semper, Warszawa 1992, s. 184. 
W listach Piotr Kochlewski kilkakrotnie wspomina młodego Dorohostajskiego. Sekretarz Radziwiłłów interesował się jego nauką ${ }^{24}$, występował w imieniu Władysława na brzeskim sejmiku, o czym pisał z Nurca do księcia Krzysztofa 15 kwietnia 1633 r. Monwid z kolei w liście z 10 maja 1634 r. prosił sędziego brzeskiego o radę w sprawie intercyzy i przejęcia majętności, podpisując się jako „WM życzliwy szwagier i służyć gotowy”. Cztery dni później również pisał do Kochlewskiego, prosząc m.in. o uregulowanie statusu swoich nieruchomości i pośrednictwo w tej sprawie u Radziwiłła ${ }^{25}$.

Listy z maja 1634 r. powstały w kilka miesięcy po weselu, na którym Piotr Kochlewski wielokrotnie zabierał głos, reprezentując rodzinę Podbereskich i Dorohostajskich. W rękopisie Biblioteki Uniwersyteckiej KUL, zawierającym m.in. unikatowe przekazy mów Kochlewskiego ${ }^{26}$, jako pierwsza została skopiowana oracja, w której dziękował królowi polskiemu ${ }^{27} \mathrm{w}$ imieniu matki panny młodej, marszałkowej bracławskiej, za podarek dla nowożeńców, przekazany przez wojewodę mścisławskiego - Mikołaja Kiszkę. Ze względu na ofiarodawcę, Kochlewski wygłosił pochwałę monarchy — ojca ojczyzny — porównał go do słońca łaskawie oświecającego poddanych oraz zapewniał:

\section{[...] ale jako Je[g]o Mść Pan Dorohostajski w Ojczyźnie strzemię krwią nieprz[yjaciels]ką dla Pana i Ojczyzny nieraz pobrudzone gotów wstąpić i wiernie Mściwą J.K.M. łaskę zasługować i na dalszą sobie zarabiać. ${ }^{28}$}

W 1634 r. Władysław objął starostwo żyzmorskie, był posłem na sejm, został wybrany na komisarza na czas wojny smoleńskiej ${ }^{29}$ i praw-

24 Wyrazem zainteresowania nauką Władysława jest następujący fragment listu Kochlewskiego z 1633 r. do Krzysztofa Radziwiłła: „Jego M. P. Dorohostajskiemu źle będzie bez dobrego dyrektora. Nie wiem jeśli go W.Ks.M. tu koło siebie upatrzysz. Mnie przyszedł na myśl P. Adam Rej [...]” (AGAD, AR, dz. V, 6956).

25 AGAD, AR, dz. V, 3216.

26 Angelika Modlińska Piekarz (zob. Ead., Siedemnastowieczna sylwa w zbiorach Biblioteki Uniwersyteckiej KUL, „Archiwa, Biblioteki i Muzea Kościelne”, 2008, s. 279) podkreśla protestancki charakter sylwy.

27 Respons Je[g]o Mci Pana Piotra Kochlewskiego dziękując imieniem Paniej Bractawskiej za podarek od Króla Je[go] Mści ofiarowany przez Jego Mści Panu Mścistawskie[go] na weselu Je[g]o Mści P[ana] Wtadystawa Dorohostajskiego 12 Febr., Lublin, rkps Biblioteki Uniwersyteckiej KUL 2629, k. 205r-206r.

28 Ibidem, k. 205v.

29 U. Augustyniak, Wtadystaw Dorohostajski, w: Ead., op. cit., s. 179. 
dopodobnie do tej funkcji odwoływał się w mowie Kochlewski. Kolejne wystąpienia sekretarza radziwiłłowskiego to podziękowania za podarunki pana młodego i za ślubny upominek od wojewody bełskiego. W oracji poświęconej darom Rafała Leszczyńskiego Kochlewski przypomniał bliskie relacje łączące Władysława z jego opiekunami:
A między inszymi Je[g]o Mści panu w[ojewo]dzie bełskiemu i samej Jej Mści pani w[ojewo]dzinej prawie rodzicielskie Je[g]o Mść Pan Dorohostajski przyznawa zaw- żdy afekty [...]. Dziękuje przy tym za upominek, a swoje z domu wszytkie[g]o swego przyjaźń i usługę Je[g]o Mści i wszystkiemu zacnemu domowi Je[g]o Mści ofiaruje. ${ }^{30}$

Władysław z Monwidów, po wczesnym osieroceniu, został powierzony opiece Krzysztofa Radziwiłła i Rafała Leszczyńskiego. Przez wiele lat przebywał na dworze w Lesznie, uczył się razem z synem wojewody bełskiego pod okiem m.in. Jana Amosa Komeńskiego ${ }^{31}$. Kochlewski dziękował Leszczyńskiemu za dar ślubny przekazany Dorohostajskim przez Daniela Naborowskiego. Nazwisko najwybitniejszego poety radziwiłłowskiego nieprzypadkowo pojawiło się w tych okolicznościach, gdyż Naborowski przed przyjęciem na służbę w Birżach był związany z wielkopolskim magnatem, razem przebywali na studiach $\mathrm{w}$ Padwie $^{32}$ i prawdopodobnie później nadal podtrzymywali przyjazne kontakty, skoro mowa Kochlewskiego wyraźnie określa pośrednictwo poety przy przekazywaniu darów ślubnych. Krótka oracja zaczyna się od starożytnego egzemplum — przykładu z dworu Filipa Macedońskiego, który zadał swoim „sapientom” pytanie o największą na świecie rzecz. Spośród takich propozycji jak: woda, słońce, góra Olimp, Atlas, Homer, król wybrał odpowiedź wskazującą na:

[...] animusz człowieczy, ten choć w małym ciele jakoby w ciasnym tarasie mieszka, przecię i przyszłe wieki jako dzisiejsze przegląda i przyszłe rzeczy na nie upatruje i świat od granice do granice przebiega i to, co ma być po śmierci ludzkiej, widzi i do samego czasem nieba przenika. ${ }^{33}$

\footnotetext{
30 Tegożdziękującza upominekJe[g]o Mści P. w[ojewo]dzie betskiemu przezP. Naborowskie[g]o ofiarowany, Lublin, rkps Biblioteki Uniwersyteckiej KUL 2629, k. 207r-208r.

31 Por. S. Herbst, Dorohostajski Wtadystaw herbu Leliwa, w: PSB, t. V/1, z. 12 (1939), s. 335.

32 Zob. J. Dürr-Durski, Daniel Naborowski. Szkic informacyjny, w: D. Naborowski, Poezje, wyd. J. Dürr-Durski, PIW, Warszawa 1961, s. 7.

33 Tegożdziękując za upominek je[g]o Mści P. w[ojewo]dzie betskiemu..., k. 207r-207v.
} 
Egzordium, odwołujące się do popularnych w okresie baroku „gadek", z pewnością zaciekawiło słuchaczy. Nawiązywało też do ulubionych motywów Naborowskiego, poszukującego np. w Czwartaku najbardziej pożądanych cech i wartości. Kochlewski, podobnie jak w innych mowach, odwoływał się do przykładów starożytnych, aby wyrazić uznanie dla przenikliwości i zapobiegliwości ojca pana młodego:

[...] nie błądził był on wielki zacnego marszałka Dorohostajskie[g]o animusz, kiedy synowi takich opiekunów i tyle dzieciństwu jego cunabula przybierał. ${ }^{34}$

Dowartościowanie odpowiedzialnych za wychowanie wcześnie osieroconego Władysława odnosiło się zarówno do ofiarodawcy prezentu - Leszczyńskiego, jak i do Krzysztofa Radziwiłła, który interesował się studiami swego krewnego i przyznawał mu „zupełne” lata w 1631 roku $^{35}$.

Kolejne dwie mowy sędziego brzeskiego były wypowiedziami skierowanymi do Władysława Monwida z podziękowaniem za ofiarowane żonie i teściowej dary. Przemawiając w imieniu Doroty Podbereskiej, Kochlewski przypomniał poprzednie, zorganizowane przez nią dwóm córkom i siostrzenicy, uroczystości weselne. Była to zarazem okazja, by zwrócić uwagę na „wiele cnot i ozdób białogłowskich”, które Podbereskie wnosiły do domu mężów. Kochlewski zapewniał, że Dorota traktuje swoich zięciów jak synów, darzy ich wielkim uczuciem, więc i takie będą z pewnością jej relacje z Dorohostajskim. Dziękując natomiast Władysławowi za upominek w imieniu żony - Elżbiety orator podkreślał wysokie przymioty pana młodego — najlepszy dar, przewyższający wszelkie materialne podarunki:

Zdobi Je[g]o Mści pana Dorohostajskie[g]o wysokie urodzenie, zdobi starożytna po obojej liniej zacność, ale dzisiejsza najbardziej zdobi go cnota, że ku matce jako syn i sługa, ku małżonce jako wierny małżonek, ku domostwu z sobą spokrewnionemu jako przyjaciel ozywać się raczy. ${ }^{36}$

$34 \quad$ Ibidem, k. 207v.

35 Kraków, rkps WAP Oddział na Wawelu, Archiwum Młynowskie Chodkiewiczów, nr 935. Informację o tym dokumencie podał J. Seredyka (por. Id., op. cit., s. 133).

36 Tegoż dziękując od jej Mści paniej Dorohostajskiej za upominek od pana mtode[g]o ofiarowany, Lublin, rkps Biblioteki Uniwersyteckiej KUL 2629, k. 207r. 
Nie wiemy, jakie dary ofiarował żonie i teściowej Dorohostajski, dla oratora nie było to najistotniejsze, zgodnie jednak z zasadami weselnej swady i zgodnie z zaleceniami ówczesnego savoir-vivre'u, należało publicznie okazać wdzięczność za te dowody afektów, a przy okazji — wygłosić pochwałę cnót pana młodego.

Oprócz mów weselnych Piotr Kochlewski wielokrotnie zabierał głos na pogrzebach: zachowały się jego oracje poświęcone Marcjanowi Tryźnie i Kossakowskiemu. Pierwsze z tych wystąpień zostało odnotowane w pamiętniku Albrechta Radziwiłła pod datą 7 lipca 1643 r. w sposób następujący:

Tegoż dnia urządzono w Brześciu u oo. Franciszkanów pogrzeb podkanclerzego z wielką wystawnością, ale bez porządku. Stały się trzy niezwykłe rzeczy: pierwsza, że choć był kapłanem i infułatem, złożono go na katafalku tylko w komży i ze stułą, dalej że w imieniu duchownych przemawiał świecki i to jakiś heretyk; trzecia, że trumna nie mogła wejść w otwór grobowca i tak ciało pozostawało przez trzy dni nie pogrzebane. ${ }^{37}$

Nazwisko sędziego ziemskiego brzeskiego nie zostało przywołane w cytowanym wyżej fragmencie, chociaż pojawiło się na innych stronach pamiętnika kanclerza, ważniejsze bowiem dla księcia Albrechta było podkreślenie nietypowej sytuacji oratorskiej. Z mowy na pogrzebie Marcjana Tryzny wynika, że o zabranie głosu poprosił Kochlewskiego brat zmarłego Gedeon, podczaszy litewski, który włożył na niego obowiązek podziękowania gościom za przybycie na żałobne uroczystości ${ }^{38}$.

Sędzia ziemi brzeskiej przemawiał nie tylko na obchodach funeralnych dostojników, wygłosił też mowę na pogrzebie swojej matki — Doroty z Madalińskich. Możemy dość dokładnie określić datę tego wystąpienia na podstawie korespondencji sekretarza radziwiłłowskiego, który pisał do księcia Krzysztofa 10 grudnia 1633 r. z Warszawy:

[...] jeno nie wiem jeśli mi droga do Polonii nie przypadnie, bo mi wczora oddano list od brata, że już matka dobrodziejka moja dogorywa. ${ }^{39}$

37 A. S. Radziwiłł, Pamiętnik o dziejach w Polsce, przet. i oprac. A. Przyboś, R. Żelewski, t. 2: 1637-1646, PIW, Warszawa 1980, s. 363.

38 Szerzej na temat tej mowy zob. M. Jarczykowa, „Papirowe materie” Piotra Kochlewskiego..., s. 143-151.

39 AGAD, AR, dz. V, 6956. 
W oracji poświęconej Benedyktowej Kochlewskiej syn wykreował zmarłą na wzór pobożnej matrony, znoszącej pokornie wszelkie trudności życiowe: wczesne osierocenie, stratę dzieci i męża. Przywołał przy tym lemiesze ${ }^{40}$, by z niego wywieść zalety matki:

[...] cnota z nią a ona z cnotą jeszcze w kolebce rość poczynała, bo w takim się narodziła domu, gdzie choć nie złotem, nie purpurą, ale pracowitą szlacheckie herby farbują się poćciwością, gdzie nie tylko na miękkiej albo pieszczonej zie$\mathrm{mi}$, ale i na twardej opoce nieśmiertelna sława starożytnem lemieszem zagony wyżyna. ${ }^{41}$

Piotr, wskazując na wartości rodu, jednocześnie podkreślał znaczenie osobistych zasług: „Piękna-ż to szata, która się zacnych przodków sprawami jako jakiemi kwiatami haftuje, ale daleko piękniejsza i świetniejsza, którą sobie kto z własnych swoich cnót zrobi”². Aby nie być posądzonym o pochlebstwo i stronniczość przy przedstawianiu zmarłej, syn przywoływał na świadków jej zalet swoich krewnych:

[...] z których jeden Je[g]o M. P. wuj i J.M.P. pamięcią to swoją jako w lata starszy zasiągł, a drugi J.M.P. wojski M.M P. i brat sławnej pamięci rodzica swego, na którego sors wychowania matki padła była, słyszeć to mógł $[\ldots] .43$

Wzmiankowani „asystenci” to prawdopodobnie Madalińscy, brat Doroty oraz Jakub Karol, wojski mścisławski ${ }^{44}$.

40 W kazaniu pogrzebowym poświęconym Chrystianowi Ambrożemu Kochlewskiemu, synowi Piotra, tak opisano ten herb: „Larissa, Ich Mościów PP. Madaleńskich ozdoba, z którego Domu starożytnego babka w prosapijej ojcowskiej nieboszczykowska, z tą inskrypcyją "Pracowity do sławy gościniec». Dwa Lemiesza pracowitą czujność i czujną pracę w zawikłanych sprawach zwycięską wynajdować pokazowały snadność" (Runo ztote cnoty dostojnej do którego poważnymi zmierzat postępkami wspaniaty mtodzian Jego Mość Pan Christian Ambroży Kochlewski, sędzic brzeski, Wrocław, Biblioteka Uniwersytecka (Teki Steinwehra Polonica varia II Fol. 37, t. 3, sygn. Akc.1949/440), k. 207r.).

41 Oratio funebris G.D. Petri Coclitis (sic!), Biblioteka Raczyńskich, rkps 378, k. 68v.

42 Ibidem, k. 68v.

43 Ibidem, k. 68v-69r.

44 Zob. U. Augustyniak, W stużbie hetmana i Rzeczypospolitej. Klientela wojskowa Krzysztofa Radziwitta (1585-1640), Wydawnictwo Naukowe Semper, Warszawa 2004, s. 295. 
W mowie oprócz krewnych „po kądzieli” znajdują się także wzmianki o rodzeństwie Piotra, kiedy bowiem zestawia on postawę matki z bohaterkami antycznymi, wyżej stawia jej stoicką postawę wobec różnych doświadczeń życiowych i wobec śmierci potomka:

[...] syna jednego w potrzebie za ojczyznę straciwszy, a drugich między odżałowanemi często policzonych oglądawszy, ani wesołem, ani smętnem razom zwyciężyć się nie dała. ${ }^{45}$

Kochlewski jako najważniejszą zaletę Doroty wymieniał jej pobożność, dobry przykład i fundacje na rzecz współwyznawców, a także troskę o staranne wychowanie dzieci:

Niechże się tym nikt nie gorszy i niech zmarłym cieniom tej ostatniej jej nie zajrzy, że pobożność nigdzie milszej i bezpieczniejszej gospody nie miała jako u tej poczciwej matrony. Ta w nieszczęściach dodawała jej mocnej ku Bogu ufności, ta wzgardzone u świata nabożeństwo słodziła, ta nie do zbiorów, ale do dobrego dziatek ćwiczenia myśli jej obracała. Ta jej wszystkich spraw wodzem. Ta w ciężkich i długich chorobach ochłodą. Ta do samej śmierci towarzyszką była. Znak tego dom, Bogu na chwałę przez nię lubo w jej bardzo trudnych czasiech wystawiony. Znakiem kilkadziesiąt dusz z niej rozpłodzonych, a jej przykładem, ćwiczeniem, napominaniem w religiej różnym przeciwnościom podległej zatrzymanych. ${ }^{46}$

Piotr Kochlewski przebywał z dala od swojej rodzinnej ziemi, służył bowiem na litewskim dworze księcia Krzysztofa już w okresie wczesnej młodości. Informował o tym w swojej mowie: „Tak mi przeszłe zbiegły lata, żem nigdy równo z rodzonemi memi obecnych nie mógł jej oddawać posług" ${ }^{47}$. Sekretarz birżański w memoriale dołączonym do testamentu zaznaczył, że Dorotą opiekował się jego brat Stanisław, „matce służąc, a zagonem ojczystym gnarując"48.

Kochlewski w mowie bardzo często posługiwał się egzemplifikacją starożytną, wspominał Katona, Brutusa, Pompejusza, mężne pogańskie

\footnotetext{
45 Oratio funebris..., k. 69v.

46 Ibidem, k. 70r.

47 Ibidem, k. 68r.

48 P. Kochlewski, Memoriat albo napomienie do matżonki i dziatek moich in vim suplimenta testamentowego..., wyd. Z. Trawicka, OiRwP, 1975, 20, s. 188.
} 
kobiety, odwoływał się do mitologii, literatury, obrazów i rzeźb antycznych. Na końcu oracji pojawiło się nawiązanie do starożytnych zwyczajów pogrzebowych, poprzez przywołanie zapalonego stosu, którym posłużył się też, żegnając Marcjana Tryznę. Wykorzystanie antycznych przykładów na pogrzebie katolika mogło być celowym zamierzeniem pozwalającym uniknąć kontrowersji wynikających z różności nabożeństwa i interpretacji Biblii. W przypadku oracji poświęconej matce nie było takiej konieczności, a jednak Kochlewski - podobnie jak w wielu innych mowach - przede wszystkim preferował egzempla starożytne.

W egzordium pożegnania matki pojawił się natomiast prawie dosłowny cytat z oracji księcia Krzysztofa, który w r. 1626, tłumacząc się z zabierania głosu na pogrzebie krewnego, Jana Albrechta Radziwiłła, powiedział, że jest to rzecz trudna i niebezpieczna:

Trudna, bo za żalem tępość języka chodzi i nigdziej barziej nie żałują jako tam, gdzie namniej mówić mogą. Niebezpieczna, bo cnót zmarłego Je[g]o Mści nie lza wspomnieć bez suspicyjej chełpliwości, nie lza pominąć bez ukrzywdzenia cnej jego osoby. ${ }^{49}$

Kochlewski na pogrzebie matki tak zapowiedział swoje wystąpienie:

Trudna, bo za tem tępość języka chodzi i nigdziej barziej nie żałują jako tam, gdzie namniej mówić mogą. Niebezpieczna, bo chwał macierzyńskich nie lza wspominać bez suspiciej chluby, a nie lza zamilczeć bez ukrzywdzenia cnoty. ${ }^{50}$

Tak dużą zbieżność wypowiedzi można tłumaczyć albo autorytetem i popularnością swady Radziwiłła, albo też współpracą Kochlewskiego przy „formowaniu” wystąpień swego pana.

Oratio funebris poświęcona matce została skopiowana w rękopisie Biblioteki Raczyńskich. W tytule przekręcono nazwisko mówcy (Coclitis), na Piotra Kochlewskiego naprowadzają jednak nie tylko aluzje biograficzne, odwołania herbowe czy cytat z Radziwiłła, ale przede wszystkim incipit mowy „Bodajbym ja był...”, który pokrywa się z początkiem mowy zanotowanym w sporządzonym przez kopistę reje-

49 Mowa ksiażęcia Je[g]o Mści Krzysztofa Radziwita wojewody wileńskiego na pogrzebie Książcia Jelg]o Mści kleckiego Radziwitta, Wrocław, rkps Biblioteki Ossolineum 196, k. $58 \mathrm{v}$.

50 Oratio funebris..., k. 68r. 
strze rękopisu Biblioteki Narodowej BOZ 855 „Bodajbym był ja też”. W tym zbiorze brak stron, na których przepisano orację, ale incipit umożliwia poszukiwania w innych manuskryptach „Mowy przy pogrzebie P. Kochlewskiego" 51 .

Najobszerniejsza część rękopisu BOZ 855 powstała na dworze Krzysztofa Radziwiłła ${ }^{52}$. W sylwie skopiowano wiele oracji hetmana, dużo mów anonimowych oraz takich, które zawierają niepełne dane o autorze. $Z$ tą ostatnią sytuacją mamy do czynienia w przypadku „rzeczy” zatytułowanej „Mowa P. Ko: na pogrzebie P. Stankiewicza”. Inicjały twórcy oraz nazwisko Stankiewicza, związanego z Radziwiłłami, pozwalają hipotetycznie rozważać autorstwo Piotra Kochlewskiego. Początek tej krótkiej oracji jest o tyle interesujący, że uzasadnia potrzebę zabierania głosu na ceremoniach funeralnych:

[...] właśnie jakoby też zbieg jaki bez świadectwa uszedł, gdy człek bez pogrzebowego zalecenia w ziemie idzie, gdyż nie tylko swym dla przykładu trzeba wiedzieć, czym kto był, jaki żywot i dokończenie miał, ale i zmarłym należy to w pamięciach ludzkich o sobie zostawić, co by po nich i z grobu żyć mogło. ${ }^{53}$

Orator przywołał funeralne zwyczaje starożytnych Greków i Rzymian, którzy „nie tylko w domu i w pokoju, gdy się powoli działo, ale i w obozach, i w oczach nieprzyjacielskich w samych wojennych trwogach i hałasach umarłych swoich pogrzebowymi czcili panegirykami" ${ }^{4}$. Mówca zastrzegał się, że powinien długo omawiać życie i zalety zmarłego Stankiewicza, ale ze względu na przeraźliwe zimno i wcześniejsze kazania, streszcza swoją orację, przytaczając jedynie starożytne epitafium: „Salve Ave et posterum vale”. Mowa była odpowiedzią w imieniu zaproszonych na „żałobny chleb”, więc orator zapewniał wdowę o życzliwym i chętnym przyjęciu tego zaproszenia.

Kochlewski często występował jako reprezentant jakiejś osoby (np. księcia Krzysztofa, przy wręczaniu podarunków ślubnych parze

51 Za pomoc w identyfikacji mowy na podstawie incipitu bardzo dziękuję Marii Barłowskiej.

52 Zob. M. Zachara, Sylwy - dokument szlacheckiej kultury umystowej w XVII wieku, w: Z dziejów życia literackiego w Polsce XVI i XVII wieku, red. H. Dziechcińska, Ossolineum, Wrocław 1980, s. 205.

53 Warszawa, rkps Biblioteki Narodowej BOZ 855, k. 20v.

54 Ibidem, k. $21 \mathrm{r}$. 
królewskiej) lub grupy osób (gdy gratulował patronowi nominacji na urząd wojewody wileńskiego). Wytypowanie go do tej roli było już sporym wyróżnieniem, a mówca miał świadomość odpowiedzialności i wagi słów wypowiadanych nie tylko we własnym imieniu.

Innym, często zabierającym głos mówcą z birżańskiego grona, był Samuel Przypkowski, który przemawiał na weselu Stanisława Kurosza ${ }^{55}$ i Stanisława Oborskiego $^{56}$, a także broniąc swobód religijnych na sejmiku w Proszowicach w 1627 r. ${ }^{57}$ Mowy te były już analizowane i nie ma wątpliwości co do ich autorstwa. Stwierdzenie to nie może się jednak odnosić do „Rzeczy przy pogrzebie”, która została skopiowana w siedemnastowiecznych rękopisach jako tekst anonimowy. Tytuł tej oracji zapisany w wileńskim manuskrypcie „Mowa na pogrzebie syna ks[ię]cia je[g]o Mści pana Krzysztofa Radziwiłła w Wiżunach 14 Aprila" oraz wzmianki o śmierci pierworodnego syna hetmana pozwalają na określenie czasu powstania i okoliczności wygłoszenia „rzeczy” — na ceremoniach pochówku Mikołaja w 1611 r.

W korespondencji dotyczącej przebiegu uroczystości funeralnych można znaleźć uwagi o mowie Salomona Rysińskiego na tym pogrzebie, co naprowadza na twórcę oracji. Konrad Patrykowski pisał bowiem do księcia Krzysztofa:

Pan Rysiński tym panom przyjaciołom, którzy się byli ówdzie na ten czas zjachali takie podziękowanie z wszelką ozdobą W.Ks.M. i tego zacnego ciała z pochwałą wszech ludzi uczynił, żeby się pewnie w druk podać godziło. ${ }^{58}$

Podobną opinię wyraził Adam Steckiewicz: „P. Rysiński w kościele panom przyjaciołom dziękował i barzo dobrze stanął" "Zakończenie

55 Dziękowanie od Je [g]o Mci Pana Stanistawa Kurosza za Jej Mć Panne Jadwige Grekówne przez Je[g]o Mść pana Samuela Przypkowskiego w Dobryniu, Warszawa, rkps Biblioteki Narodowej BOZ 823, k. 97v. Szerzej o tej mowie por. M. Trębska, op. cit., s. 159-160.

56 Dziękowanie za jej Mćpannę ptocka od Je[g]o Mci pana Oborskiego przez Je[g]o Mci pana Samuela Przypkowskiego A[nno] 1630, Warszawa, rkps Biblioteki Narodowej BOZ 823, k. 58r. Szerzej na temat oratorstwa weselnego Samuela Przypkowskiego zob. M. Jarczykowa, Mowy weselne Krzysztofa Radziwitta, Piotra Kochlewskiego i Samuela Przypkowskiego, „Białoruskie Zeszyty Historyczne”, 2012, 37, s. 34-36.

57 Zob. L. Chmaj, Samuel Przypkowski na tle pradów religijnych XVII wieku, PAU, Kraków 1927, s. 17-18.

58 AGAD, AR, dz. V, 11399, list z Wiżun z 16 IV 1611.

59 AGAD, AR, dz. V, 1561, list z Wiżun z 16 IV 1611. 
mowy wygłoszonej w Wiżunach wyraźnie wskazuje, że jest to podziękowanie za udział w pogrzebie:

[...] pewna rzecz, że rodzicom większa połowica tego żalu ubędzie, gdy się o ich uszy obije, z jakąście się WMM chęcią ku ozdobie tej żałosnej posługi stawić raczyli i żal swój spólny z żalem Ichmści oświadczyli, zaniechawszy potrzeb i zabaw swoich rozmaitych, nie dbając nic na niewczasy podróżne, nie obruszając się nieustawicznym niebem i rozpuszczoną ziemią, a tym jeszcze większy dank uczynności WMM odnosi, że temu jest wyrządzona, który nullis merito suis na nie nie zarobil, ani zarobić może [...] wdzięcznie my to tedy z Książęciem Jmcią naszym Mściwym Panem od WM Panów przyjmując życzymy, aby Pan Bóg Wszechmogący w dobrym zdrowiu przy rozmnożeniu wszelkich pociech długo WMM chował, a takich i tym podobnych żalów wiecznie uchował. ${ }^{60}$

Z listu Steckiewicza wynika, że w imieniu przyjaciół dziękował Piotr Pac, wojewoda mścisławski, a kazanie pogrzebowe wygłosił kaznodzieja popielski ks. Jan Gierdwił. Rysiński, pomimo zapowiedzi, że patronująca sztuce wymowy Minerwa jest w odniesieniu do jego umiejętności „szczupła” i że nie ma wprawy w wygłaszaniu „gładkich słów”, przedstawił „rzecz”, w której zawarł cytaty z Wergiliusza (Eneida) i Seneki oraz wielokrotnie przytaczał Biblię: księgi Koheleta, Hioba i Zachariasza. Poza tym dał świadectwo bardzo dokładnej pamięci o pogrzebach innych członków rodu Radziwiłłów, wspominając dzień pochówku Krzysztofa „Pioruna”:

Dzisiaj bowiem siedm lat i siedm dni, a to jest znaczy i obwołany klimakteryk jakośmy na tym placu, w takiej barwie, takowy akt znacz[n]y odprawowali, wprawdzie w większej gromadzie i w żałobniejszej postawie, bo tak na on czas wielkiego Radziwiłła wiele ich żałowało. ${ }^{61}$

Rysiński przywiązywał wielką wagę do wyznaczania odpowiedniej, symbolicznej daty pogrzebów, kiedy bowiem zmarł młodszy syn księcia Krzysztofa proponował mu, aby ten żałobny akt odprawił w czwartek, podobnie jak inne, wcześniejsze pochówki Radziwiłłów ${ }^{62}$.

60 Kraków, rkps Biblioteki Czartoryskich 439 IV, s. 749.

$61 \quad$ Ibidem, s. 747.

62 Zob. list z Wilna z 18 III [1617], AGAD, AR, dz. V, 13601. 
W rękopisie Biblioteki Czartoryskich oracja Rysińskiego została przepisana tuż przed okolicznościowymi wierszami ułożonymi na egzekwia syna księcia Krzysztofa, a podpisanymi przez Salomona ${ }^{63}$. Paremiograf bardzo czynnie angażował się w przygotowanie Radziwiłłowskich ceremonii pogrzebowych i tworzył wiele wymaganych do oprawy uroczystości tekstów. „Rzecz przy pogrzebie” potwierdza jego umiejętności nie tylko w zakresie komponowania łacińskich nagrobków, ale także świadczy o sprawności krasomówczej w języku polskim. Książę Krzysztof prosił zaufanego sługę o wygłoszenie kolejnej „rzeczy” na pogrzebie syna Jerzego, ale Rysiński, odmawiając, usprawiedliwiał się, że nie pozwala mu na to zdrowie, słaba pamięć i nadmiar obowiązków związanych z przygotowaniem pochówku. Nie wiemy więc, kto wygłosił zachowaną w kilku odpisach orację ${ }^{64}$ na pogrzebie Jerzego Radziwiłła, chociaż w jednym przekazie tytuł wskazuje na „sługę jednego”, zacieśniając krąg możliwych twórców do famulusów radziwiłłowskich.

Fragment egzordium w oracji poświęconej Mikołajowi, mówiący o wykonywaniu polecenia księcia "przystojnego podziękowania” za oddaną „tę pierwszą i ostatnią posługę synaczkowi Księcia J.M.”, bardzo przypomina słowa wypowiedziane siedem lat później na pogrzebie Jerzego. Zakończenie obu oracji na pogrzebach synów hetmana jest prawie identyczne, co mogło jednak wynikać z konwencjonalnych zwrotów w tego typu podziękowaniach. Inna zbieżność to peryfrastyczne nazywanie Hioba człowiekiem wielkiej, niewypowiedzianej cierpliwości. Są to zbyt nikłe ślady, by bezwarunkowo proponować autorstwo Rysińskiego w odniesieniu do „rzeczy” z 1617 r. Warto jednak zauważyć, że orator pochodził $\mathrm{z}$ grona zaufanych sług hetmana, co sugestywnie zaznaczył we wstępie, wspominając także, że zabiera głos na wyraźne życzenie patrona. Może więc Rysiński, pomimo wstępnego „krygowania

63 Omówienie mowy oraz nagrobka, inskrypcji na srebrnej tablicy i na sarkofagu Mikołaja zob. M. Jarczykowa, Wielkie rytuaty dla matych Radziwittów. O tekstach towarzyszacych śmierci dzieci w XVII wieku, „Napis”, seria 16: „Literatura i rytuały”, Warszawa 2010, s. 107-114.

64 Wrocław, rkps Biblioteki Ossolineum 231, k. 62v-65r. Mowa zachowała się także w Lublinie, w rękopisie Biblioteki Uniwersyteckiej KUL 2629 pt. Mowa na pogrzebie syna Ks[ięcia J.M. Pana hetmana pol[nego] W.Ks.L., k. 182r-184r. Szerzej o tej mowie zob. M. Jarczykowa, Literacka „oprawa” smierci i pogrzebu Jerzego Radziwitta (1616-1617), w: Sarmackie theatrum, t. 4: Studia o literaturze i ksiażce dawnej, red. R. Ocieczek, M. Jarczykowa, UŚ, Katowice 2009, s. 39-58. 
się”, wygłosił jednak mowę zgodnie z poleceniem Radziwiłła. O tym, że książę Krzysztof nie uwzględniał próśb o odwołanie z funkcji oratora, może świadczyć list Pawła Orlicza, który został wyznaczony do wygłoszenia kazania na pogrzebie Anny Wazówny ${ }^{65}$. Z relacji z toruńskich uroczystości wiemy, że Orlicz, pomimo obaw i prośby przesunięcia na inną osobę „tego kielicha”, wystąpił na pogrzebie i dobrze poradził sobie jako kaznodzieja.

$\mathrm{Na}$ dworze w Birżach dbano o wysoki poziom kultury żywego słowa. Hetman w zaleceniach przygotowanych dla preceptorów syna Janusza uczulał nauczycieli na ten aspekt wykształcenia księcia, sam był sprawnym i popularnym oratorem, więc z pewnością doceniał w swoim otoczeniu ludzi nie tylko kompetentnie redagujących listy i rozmaite pisma związane z działalnością polityczną i wojskową, ale też mówców potrafiących na różnych uroczystościach prywatnych i publicznych umiejętnie zabrać głos.

W siedemnastowiecznej Rzeczypospolitej przywiązywano wielką wagę do kompetencji retorycznych, które pozwalały na sprawne posługiwanie się żywym słowem w różnych okolicznościach. Według Marii Barłowskiej, oratorstwo było dla dawnych Polaków:

Świętem i chlebem powszednim [...] służyło nadawaniu codzienności wymiaru szczególnego: pewnej celebry, powagi, wzniosłości, poprzez odnoszenie się do podstawowych wartości i skupiającej się wokół nich wspólnoty. [...] Mowy uświetniały więc wydarzenia z życia prywatnego i publicznego, nadając obydwu tym sferom podobne rysy zbiorowego theatrum, na którym celebrowano współuczestniczenie we wspólnocie wolnych Sarmatów. ${ }^{66}$

Mówcy z birżańskiego dworu aktywnie wpisywali się w to theatrum, zabierając głos na wielu ceremoniach mniej lub bardziej oficjalnych. Oracje Piotra Kochlewskiego kierowane były do węższego lub szerszego audytorium, do wspólnoty wyznaniowej, rodzinnej, do przyjaciół z hetmańskiego dworu lub do słuchaczy zgromadzonych na oficjalnych uroczystościach

65 „Zrozumiawszy wolą W.Ks.Mości w dyrekcyjej tego, co służy ad [...] standum tak zacnego aktu submituję się ex parte mia we wszystkim prócz kazania nad ciałem królewny Jej Mci ś.p. Minor sum Domine. Proszę W.Ks.Mości można li, aby był ten kielich na kogo inszego przeniesiony" (list z 25 VI 1636; AGAD, AR, dz. V, 10929). ${ }_{66}$ M. Barłowska, Na swady sarmackiej placu. O kulturze oratorskiej wieku XVII, Wydawnictwo Szumacher, Kielce 2001, s. 6-7. 
związanych z koronacją królewską czy z pogrzebem dostojnika kościelnego. Orator umiejętnie dostosowywał się do tych sytuacji. Przemawiając na weselu ministra kalwińskiego, przypominał zgromadzonym zalety znanego im osobiście nowożeńca, odwoływał się do wzorca idealnego duszpasterza, zgodnie z zaleceniami weselnej swady chwalił stan małżeński. Większymi umiejętnościami musiał wykazać się na weselu Dorohostajskiego, przemawiał bowiem wielokrotnie, w imieniu różnych osób. Serie oracji dziękczynnych nie były niczym wyjątkowym w praktyce staropolskich mówców. $\mathrm{Na}$ przykład, Bartłomiej Siemichowski na weselu Cyrylusa Taszyckiego cztery razy zwracał się do wyróżnionych uczestników ceremonii, składając im zwyczajowe podziękowania. Według oceny Małgorzaty Trębskiej:

Wystąpienia Siemichowskiego są bardzo surowe w stylu, pozbawione jakichkolwiek ornamentów, zredukowane niemal wyłącznie do funkcji dziękującej. Mówca nie stara się ani zaciekawić swoich słuchaczy, ani poruszyć, w żaden sposób nie dąży do sprawienia im przyjemności estetycznej, nie chce ich nawet pouczyć ani napomnieć. ${ }^{67}$

Opinii takiej nie można wydać w odniesieniu do oracji Kochlewskiego, który, przemawiając na weselu Władysława Dorohostajskiego, stosował różne sposoby aktywizowania audytorium: odwoływał się do biografii i koligacji nowożeńców, wykorzystał rozbudowaną zagadkę, aby zaciekawić słuchaczy. Sędzia ziemi brzeskiej często przemawiał także na pogrzebach, podobnie jak jego patron - Krzysztof Radziwiłł. Zapraszano ich nawet do krasomówczych wystąpień na pogrzebach hierarchów Kościoła katolickiego. Obaj mówcy musieli wykazać się dużą dyplomacją i zręcznością, aby nie poruszać drażliwych spraw wyznaniowych, czemu służyło sięganie do przykładów mitologicznych i z historii starożytnej. Można uznać, że w środowisku birżańskim została wypracowana skuteczna metoda stosowania przekonujących, ale obojętnych dla kultury kontrreformacji sposobów przemawiania. Książę i jego zaufany sługa często wykorzystywali przy tym argumentację emocjonalną, mówili w sposób bezpośredni, stronili od łacińskich cytatów i nadmiaru erudycyjnych popisów.

Inny styl stosował w swoich wypowiedziach funeralnych Salomon Rysiński. Jego mowy wygłaszane na pogrzebach dzieci księcia Krzysztofa

67 M. Trębska, op. cit., s. 261. 
nasycone są przytoczeniami i egzemplami biblijnymi, często w oracjach pojawiały się też cytaty z literatury starożytnej. Uczony filolog potrafił śmierć małych Radziwiłłów ująć w teologiczne reguły i wykorzystać swoje mowy do celów parenetycznych. Oracje na pogrzebach niemowląt rzadko kopiowano w siedemnastowiecznych manuskryptach. Może wiązało się to z obchodami pogrzebowymi, które nie były tak wystawne i starannie przygotowywane jak w rodzinie książęcej, gdzie nawet niemowlęta żegnano z wielką pompą. „Rzeczy” Rysińskiego powielano w sylwach nie tylko z powodu ich wyjątkowości, uznano je raczej za godne utrwalenia ze względu na ogólne rozważania paremiologa na temat śmierci oraz dopracowaną formę i kompozycję.

Do czasów współczesnych oracje z birżańskiego kręgu zachowały się głównie w rękopisach, jedynie dwa wystąpienia hetmana (na pogrzebach Krzysztofa Mikołaja Sapiehy ${ }^{68}$ i Dadziboga Słuszkii ${ }^{69}$ ) zostały wydane drukiem. W wielokrotnie przepisywanych mowach Radziwiłła, zazwyczaj zachowywano personalia i informacje o godności przemawiającego. Wyjątkiem są tu jednak pojedyncze przekazy „rzeczy” Kochlewskiego i Rysińskiego. O autorstwie paremiologa można snuć jedynie przypuszczenia na podstawie wskaźników zewnętrznych, wzmianek w korespondencji oraz usytuowania mowy w rękopisie. Sędzia ziemi brzeskiej był natomiast wymieniany jako autor i to zarówno w tytułach mów, jak i w indeksach zawartości rękopisów. Można go uznać za najbardziej aktywnego mówcę z birżańskiego grona. Wynikało to może ze specyfiki zajmowanego przez niego stanowiska: był de facto kanclerzem rodu Radziwiłłów, co zmuszało go nie tylko do sprawnego operowania słowem pisanym, ale także wykazywania się biegłością w wymowie ${ }^{70}$. Zachowane dystychy Kochlewskiego mogły też służyć jako zwięzłe podsumowania krasomówczych wypowiedzi, zwłaszcza na pogrzebach,

68 Mowa Jaśnie Oświeconego p. Kr[z]ysztofa Radziwit[t]a książęcia na Birżach i Dubinkach, hetmana polnego W.Ks.L. [...] na pogrzebie Wielmożnego a M[i]t[o]ściwego pana Jego M[i]tości p. K[r]zysztofa Sapiehy, wojewodzica wileńskiego, pisarza W.Ks.L. [...] Różana 1632, Biblioteka Narodowa, sygn. W. 1. 3533.

69 Rzecz Jaśnie Oświeconego Pana Jego Mści Pana Krzysztofa Radziwit[t]a, ksiażęcia na Birżach i Dubinkach, hetmana polnego W.Ks.Lit[ewskiego] do utrapionych rodziców zmartego, a nigdy nieodżatowanego Jego Mści Pana Dadziboga Wtadystawa Stuszki przy pogrzebie jego miana, Biblioteka Narodowa, sygn. XVII. 3. 1433.

${ }_{70}$ Zob. R. Heidenstein, Cancellarius sive de dignitate et offcio cancellarii Regni Poloniae, ed. A. Kempfi, PWN, Warszawa 1960, s. 44. 
gdyż większość z nich obracała się w kręgu tematyki tanatologicznej. Dalsze poszukiwania w rękopisach ujawniające kolejne wystąpienia Radziwiłłów i ich dworzan mogą przyczynić się do lepszego zrozumienia kultury tego środowiska ${ }^{71}$.

\section{The Culture of Oratory in the Court of Radziwiłt of Birże. Unknown Speeches of Piotr Kochlewski and Salomon Rysiński}

The article presents some newly discovered and hitherto unanalyzed speeches of two trusted courtiers of Krzysztof Radziwiłł, namely Piotr Kochlewski and Salomon Rysiński. Piotr Kochlewski's orations have been found in the Central Archives of Historical Records in Warsaw (a speech at the wedding of Pawel Demitrowicz), in the University Library at the Catholic University of Lublin (four orations at the wedding of Władysław Dorohostajski) and in the Raczyński Library (a speech at the funeral of his mother - Dorothy from Madalińscy). It is thought that Piotr Kochlewski is also the author of a speech about Stankiewicz, which is copied in a manuscript kept in the National Library of Poland.

One can learn about the speeches of Solomon Rysiński from the letters concerning the funerals of Krzysztof Radziwitł's children. Describing the course of the farewell ceremony of Nicholas (d. 1611), Steckiewicz and Patrykowski expressed their good opinion of the oration given by Rysiński, who thanked the guests. This speech was copied into the Czartoryski Library manuscript (along with poems signed with Rysiński's name) and into a manuscript kept in the Lithuanian State Historical Archives. Krzysztof Radziwiłt also asked Rysiński to speak at the funeral of his younger son, Jerzy. Another manuscript found in the former Ossolineum Library in Lviv includes a speech given by "a servant" at Jerzy's funeral. Perhaps the author of this oration is also Rysiński, although he himself justified the denial of this order to speak at the funeral in his letter to Krzysztof Radziwiłł.

\footnotetext{
71 Mowy protestantów nie były chętnie wydawane, nieraz pomijano je przy kopiowaniu manuskryptów, stosując kryterium wyznaniowe. Zob. M. Barłowska, Swada i milczenie..., s. 172.
} 